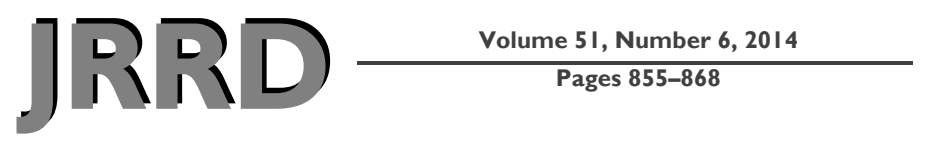

\title{
Prevalence of heat and perspiration discomfort inside prostheses: Literature review
}

\author{
Kamiar Ghoseiri, PhD Candidate; Mohammad Reza Safari, PhD* \\ Department of Orthotics and Prosthetics, University of Social Welfare and Rehabilitation Sciences, Tehran, Iran
}

\begin{abstract}
People with limb amputation deal with thermal stresses in their daily activities. Unfortunately, in the majority of this population, all thermal transfer mechanisms, including convection, radiation, evaporation, and conduction, can be disturbed due to the prosthetic socket barrier, decreased body surface area, and/or vascular disease. The thermal environment inside prosthetic sockets, in addition to decreased quality of life and prosthesis use, comfort, and satisfaction, could put people with amputation at high risk for skin irritations. The current review explores the importance of thermal and perspiration discomfort inside prosthetic sockets by providing an insight into the prevalence of the problem. The literature search was performed in two databases, PubMed and Web of Knowledge, to find relevant articles. After considering the review criteria and hand-searching the reference sections of the selected studies, 38 studies were listed for review and data extraction. This review revealed that more than 53\% of people with amputation in the selected studies experienced heat and/or perspiration discomfort inside their prostheses. In spite of great technological advances, current prostheses are unable to resolve this problem. Therefore, more attention must be paid by researchers, clinicians, and manufacturers of prosthetic components to thermal-related biomechanics of soft tissues, proper fabrication technique, material selection, and introduction of efficient thermoregulatory systems.
\end{abstract}

Key words: amputation, amputee, comfort, heat, perspiration, prosthesis, residual limb, skin, socket, temperature.

\section{INTRODUCTION}

Global prevalence estimates of amputation are difficult to obtain due to incomplete international disability databases and limited resources to record national levels of disabilities [1]. The United States had nearly 1.6 million people with amputation based on 2005 reports [2]. In the United States, it could be estimated that the population with amputation will increase to 3.6 million by 2050 [2]. It could be estimated that nearly 30 million people in Africa, Asia, and Latin America require prostheses, orthoses, and other assistive devices [1]. Annually in the United Kingdom, there are nearly 5,000 new referrals to prosthetic service centers [3]. These statistics could represent high demand for prostheses in the near future.

The socket is the main component of a prosthesis that primarily provides structural coupling, control, and proper transfer of forces at its interface with the residual limb [4]. Socket comfort directly affects function and extent of prosthesis use in people with amputation [5]. Good prosthesis fit and suspension requires a snug total contact fit that consequently limits ventilation and air circulation at the socket-skin interface. Inappropriate socket ventilation and low moisture permeability of socket walls leads to higher residual-limb skin temperature and perspiration accumulation inside the socket. These consequences could negatively affect quality of life, prosthesis

Abbreviations: Botox $=$ Botulinum toxin, $\mathrm{CI}=$ confidence interval, $\mathrm{MeSH}=$ medical subject heading.

*Address all correspondence to Mohammad Reza Safari, PhD; Department of Orthotics and Prosthetics, University of Social Welfare and Rehabilitation Sciences, Tehran, Iran, 1985713834; +9821-22180010.

Email: m.r.safari.k@gmail.com, mo.safari@uswr.ac.ir http://dx.doi.org/10.1682/JRRD.2013.06.0133 
suspension, prosthesis use, and activity level. Moreover, they cause discomfort, skin irritation, skin maceration, friction blisters, infection, unpleasant odor, and an environment for bacterial invasion to hair follicles of the residual limb [6-17]. Findings of a survey in 2001 revealed that thermal discomfort with the prosthetic socket could decrease quality of life in many people with amputation [12]. In another study, 60 to 70 percent of people with amputation reported high perspiration inside their prosthetic socket as a major problem [18].

Skin care of the residual limb is of great importance in that any skin irritation could endanger load bearing and prosthesis use in spite of appropriate socket fit [15,1920]. Skin problems that could easily be seen in people with amputation include those with mechanical sources (epidermoid, cysts, calluses, verrucous hyperplasia), allergic reactions (inflammation, eczema, contact dermatitis, rash), and fungal or bacterial infections [14,21]. In the population with amputation, the presence of at least one skin problem is estimated to be between 32 and 73.9 percent [22-24]. Skin temperature increase is a sign of tissue stress and its presence with slight moisture could cause friction blisters [25-27]. Naylor showed that skin with slight moisture is more susceptible to blisters than wet or dry skin [28]. This same skin condition occurs inside the prosthetic socket. Legro et al., in their survey to determine important issues about prosthesis use by people with amputation, revealed that prevention of skin blisters is one of the three most important issues [16].

Findings of a study by Peery et al. revealed that a $1{ }^{\circ} \mathrm{C}$ to $2^{\circ} \mathrm{C}$ increase in residual-limb skin temperature inside the prosthetic socket could cause discomfort [29]. Thermal comfort is a general sense of the body that would be disturbed in the presence of limb temperature imbalance. It means that if one part of the body is hot and another is cold, the person feels thermal discomfort [30]. According to the standards of the American Society of Heating, Refrigerating, and Air Conditioning Engineers, thermal comfort is a satisfactory condition from the environment temperature [30-31]. Limited attention has been paid to the study of thermal discomfort inside the prosthetic socket [32]. The majority of temperature recordings of the residual limb are performed to detect the level of reamputation surgery, vascular integrity, and exploration of phantom pain syndrome [33]. A general insight regarding the prevalence and importance of heat and/or perspiration discomfort with prostheses could draw more attention to resolving this long-lasting problem. The cur- rent study was designed to review the literature and explore the prevalence of heat and/or perspiration discomfort by providing a general insight for researchers, clinicians, and prosthetic component manufacturers to resolve the problem.

\section{METHODS}

An electronic literature search was performed in two databases, PubMed and Web of Knowledge (now called Web of Science), to find relevant articles. The selection of two databases was based on the guidelines of the American Academy of Orthotists and Prosthetists and an evidence report that determined their appropriate coverage for the most relevant journals in the field of orthotics and prosthetics [34]. The chosen time period was the first date possible for each database until November 2013. The search strategy was based on the Patient, Intervention, Comparison, and Outcome system, using the following key words combined as a search string:

1. "Residual limb” OR stump* OR “amputation stumps" [medical subject heading (MeSH)]

2. Amputee* $[\mathrm{MeSH}]$ OR amputation [MeSH]

3. Search 1 OR 2

4. Socket*

5. Prosthesis OR prostheses OR "artificial limbs" [MeSH] OR (artificial AND limb)

6. Search 4 OR 5

7. Comfort* OR discomfort*

8. Hyperhidrosis [MeSH] OR hyperhydrosis OR sweat [MeSH] OR sweating [MeSH] OR perspiration*

9. Hydration*

10. "Skin temperature” [MeSH] OR (skin AND temperature)

11. Heat*

12. Thermal

13. Search 7 OR 8 OR 9 OR 10 OR 11 OR 12

\section{Search 3 AND 6 AND 13}

The results of both databases were entered into EndNote reference management software (Thomson Reuters; Philadelphia, Pennsylvania), and all duplicate results were removed. Then, two independent reviewers assessed the title and abstract of all identified studies for adaptation to the inclusion criteria. The reviewers included published journal articles written in English that directly or indirectly reported heat and/or perspiration 
discomfort with prostheses and with subject participants with amputation.

Moreover, review articles, case reports, case studies, and technical notes were excluded. Although none of the review articles reported the heat and/or perspiration prevalence, the reference sections of these articles were searched to find any potential studies that were not found in the electronic search.

Following abstract-based assessment, the full text of all selected studies was reviewed to check their adaptability with review criteria. Additionally, the reference sections of the selected full-text articles were examined to find other potential studies to extend the included articles. The reviewers independently extracted demographic, methodological, and results data from the selected studies. For methodological data extraction, the design, assessment method, main outcome measure, and total number or percentage of the study population with heat and/or perspiration discomfort were defined. Finally, the results of both reviewers were compared and all differences were resolved through discussion.

To determine the prevalence of people with amputation and heat and/or perspiration discomfort in the selected studies, the weighted summary proportions with a 95 percent confidence interval (CI) were calculated using
MedCalc statistical software version 13.0.0 (MedCalc Software; Ostend, Belgium).

\section{RESULTS}

A preliminary literature search in two databases without consideration of review criteria identified 330 abstracts. Application of review criteria caused the removal of 283 abstracts. Two reviewers assessed the full text of 47 remaining studies, i.e., 14 percent of the preliminary results. Following a full-text review, 13 full-text articles were removed from the list due to nonfulfillment of one or more review criteria. In addition, two more studies were removed from the list because their full texts were not accessible [35-36]. With the addition of 6 studies after reference section examination of the selected full texts, 38 studies in total were identified for data extraction. Figure 1 shows the procedure for study selection.

Table 1 represents the demographic characteristics of subjects in the selected studies [6-7,11-13,16$18,21,29,37-64]$. The number of subjects in the studies ranged from $4[43,48]$ to 581 [59]. Unfortunately, the demographic characteristics of participants were heterogeneous and difficult to compare. Based on those studies

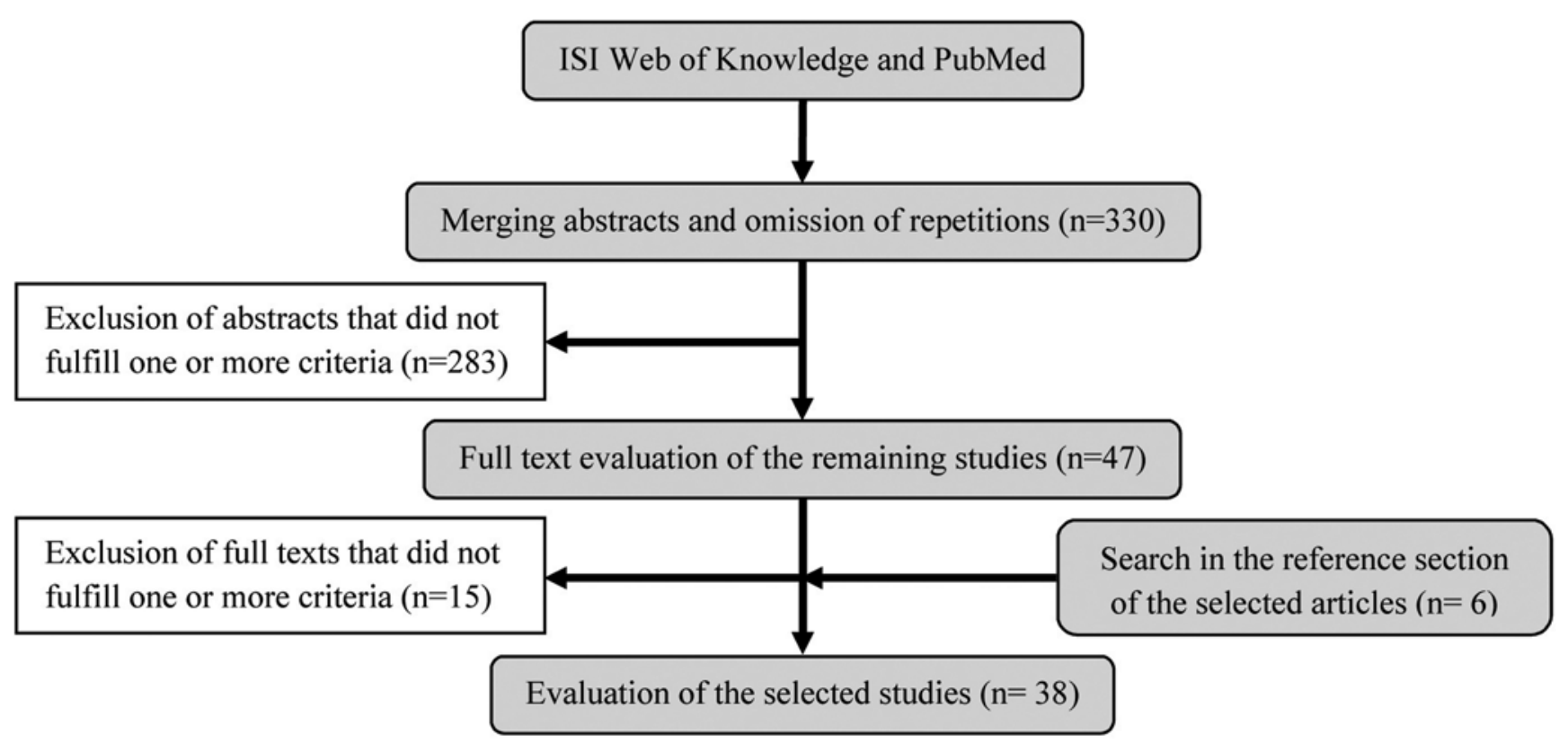

Figure 1.

Procedure for selection of studies from two databases. 
Table 1.

Demographic characteristics of participants in selected studies.

\begin{tabular}{|c|c|c|c|c|c|}
\hline Study & $\begin{array}{l}\text { Participants } \\
\text { (n) }\end{array}$ & $\begin{array}{c}\text { Age (yr), } \\
\text { mean } \pm \text { SD (range) }\end{array}$ & Amputation & $\begin{array}{l}\text { Time Since Amputation } \\
\text { (yr), mean } \pm \text { SD (range) }\end{array}$ & $\begin{array}{c}\text { Daily Prosthesis Use (h), } \\
\text { mean } \pm \text { SD (range) }\end{array}$ \\
\hline Kejlaa, 1993 [37] & 48 & $46.3(4-83)$ & UL & $23.3(0-51)$ & $>8$ \\
\hline Cluitmans et al., 1994 [39] & 26 & NR & LL & 11.05 & NR \\
\hline Datta et al., 1996 [13] & 54 & $48.35(22-80)$ & LL & $0.40(0.03-2)$ & 10.42 \\
\hline Pereira et al., 1996 [40] & 30 & $(15-50)$ & UL & NR & $>9$ \\
\hline Boonstra et al., 1996 [42] & 8 & $41(24-62)$ & LL & $16(2-50)$ & NR \\
\hline Leow et al., 1997 [43] & 4 & NR & UL & $\geq 2$ & (8-10) \\
\hline Dasgupta et al., 1997 [44] & 27 & $49.87 \pm 13.57(21-76)$ & LL & $16.68 \pm 15.09(1-52)$ & $14.45 \pm 2.5(8-18)$ \\
\hline Lake \& Supan, 1997 [18] & 56 & $52.9(15-85)$ & LL & 6.5 & NR \\
\hline Hachisuka et al., 1998 [45] & 32 & $44.5 \pm 16$ & LL & $0.90 \pm 1.15$ & NR \\
\hline Legro et al., 1999 [16] & 92 & $55(22-81)$ & LL & $(1-53)$ & NR \\
\hline Hatfield \& Morrison, 2001 [49] & 56 & $51.45 \pm 17.9(11-78)$ & LL & $16.3(1-69)$ & NR \\
\hline Hachisuka et al., 2001 [17] & 83 & $53.4 \pm 14.4$ & LL & $14.8 \pm 15.2$ & $>7$ \\
\hline Hagberg \& Brånemark, 2001 [12] & 90 & $48(20-69)$ & LL & $22(2-52)$ & $>10$ \\
\hline Dillingham et al., 2001 [50] & 78 & $40.4 \pm 13.4$ & LL & $7.5 \pm 2.8$ & $11.5 \pm 4.7$ \\
\hline Davidson, 2002 [51] & 70 & NR & UL & NR & $1.75 \pm 1.45$ \\
\hline Coleman et al., 2004 [52] & 13 & $49.4 \pm 9.6(31.5-65.8)$ & LL & $24.4 \pm 11(4.7-39.3)$ & 10.3 \\
\hline Peery et al., 2005 [29] & 5 & $44 \pm 14$ & LL & $\geq 2$ & 8 \\
\hline Van de Weg \& Van der Windt, 2005 [53] & 220 & $62.1 \pm 17.5$ & LL & $16.7 \pm 16.2$ & $>6$ \\
\hline Meatherall et al., 2005 [54] & 41 & $(40-88)$ & LL & $\geq 0.5$ & $11.25 \pm 5.25$ \\
\hline Biddiss \& Chau, 2007 [55] & 242 & $26.25 \pm 10.5(1-80)$ & UL & $(0.4-6.6)$ & $4.37 \pm 2.12$ \\
\hline Charrow et al., 2008 [56] & 8 & $28.5(20-42)$ & UL, LL & $0.68(0.33-1.16)$ & NR \\
\hline Østlie et al., 2012 [61] & 224 & 53.7 & UL & 24 & NR \\
\hline Yang et al., 2012 [62] & 247 & $62 \pm 3$ & UL, LL & $38 \pm 3$ & NR \\
\hline Ali et al., 2012 [63] & 9 & $49.3 \pm 15.0$ & LL & $\geq 3.5$ & NR \\
\hline Gholizadeh et al., 2013 [64] & 90 & $47.77 \pm 7.0$ & LL & $23.80 \pm 4.2$ & $11.80 \pm 3.34$ \\
\hline
\end{tabular}

that reported the mean participant age, time since amputation surgery, and daily prosthesis use, these values were $48.12 \pm 8.78 \mathrm{yr}, 15.73 \pm 9.71 \mathrm{yr}$, and $9.89 \pm 3.55 \mathrm{~h}$, respectively (Table 1). The lower limbs were evaluated more than upper limbs in the selected studies. Moreover, three studies evaluated both upper and lower limbs; in two additional studies, the evaluation was based on upper, lower, and multiple limbs.
Table 2 represents methodological evaluations of the selected studies [6-7,11-13,16-18,21,29,37-64]. Studies that reported heat and/or perspiration discomfort the most were conducted in 1996, 2001, and 2012, each with four studies. As can be seen from Table 2, the heat and/or perspiration discomfort inside prostheses is a long-lasting issue. With respect to study design, 27 were descriptive observations, 9 were prospective experiments, and 2 were retrospective observations. Survey and medical 
Table 2.

Methodological characteristics of selected studies.

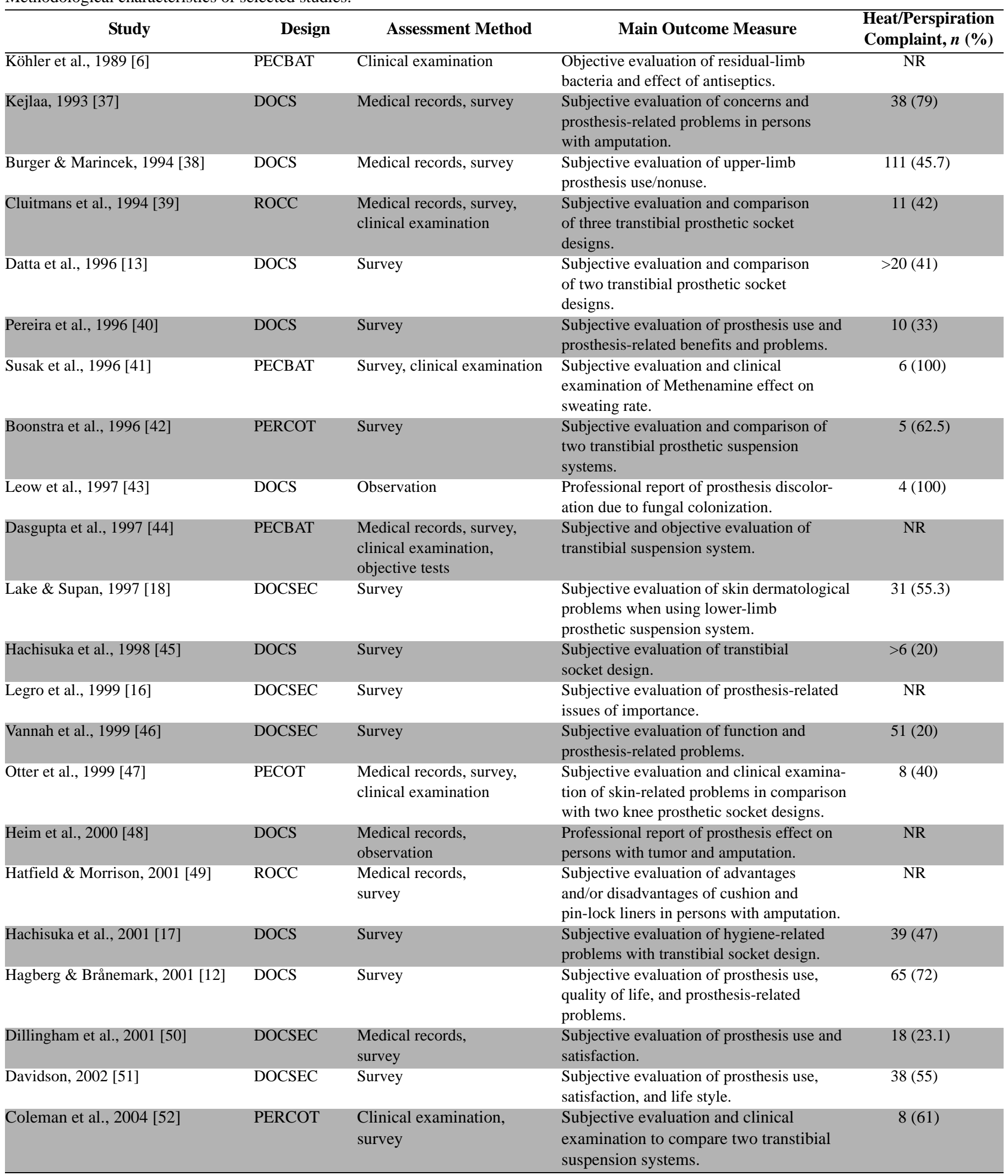


Table 2. (cont)

Methodological characteristics of selected studies.

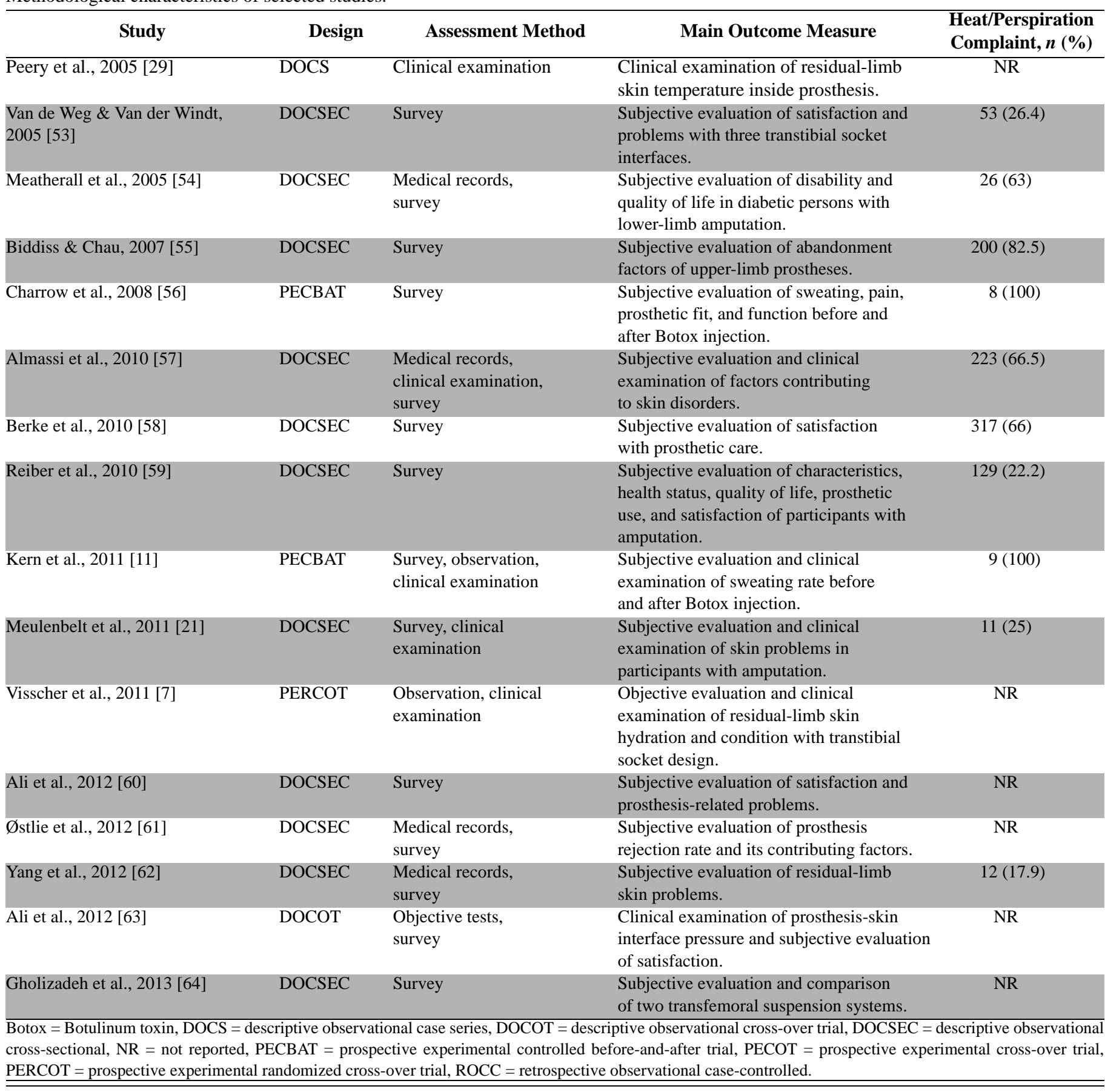

records were the most used assessment methods in the selected studies, followed by clinical examination. Subjective evaluation of people with amputation and prosthesis-related issues by standard or author-designed questionnaires was the main outcome measure for the majority of the selected studies.
In the current review of the literature, the number and percentage of the population experiencing heat and/or perspiration were extracted based on participants' response to thermal-related trials and questions in surveys. Of the 38 selected studies for this review, 27 reported the total number of participants with heat and/or 
perspiration discomfort (Table 2). Subjects from these studies were pooled (total: 3,126) to calculate the weighted summary proportion of those with heat and/or perspiration discomfort (Figure 2). The results revealed that these studies had a significant heterogeneity (Cochran $\mathrm{Q}=749.97, p<0.001$ ) and inconsistency $\left(\mathrm{I}^{2}=\right.$ 96.53); therefore, the true proportion estimate significantly varied between different studies. Due to inconsistency between the true estimates of the reviewed studies, we used the random effects model to calculate weighted summary proportion. In the random effects model, the summary proportion is calculated based on the weighted average of proportions reported in the studies [65].
According to the calculations, at least 53.68 percent (with a 95\% CI of 43.63-63.58) of people with amputation have complaints regarding heat and/or perspiration inside prostheses. Figure 2 shows the heat and/or perspiration discomfort proportion and 95 percent CI for each individual study $(n=27)$ and the weighted summary proportion presented in the forest plot.

\section{DISCUSSION}

In spite of the great importance of thermal discomfort inside prostheses and its subsequent effects on skin integrity,

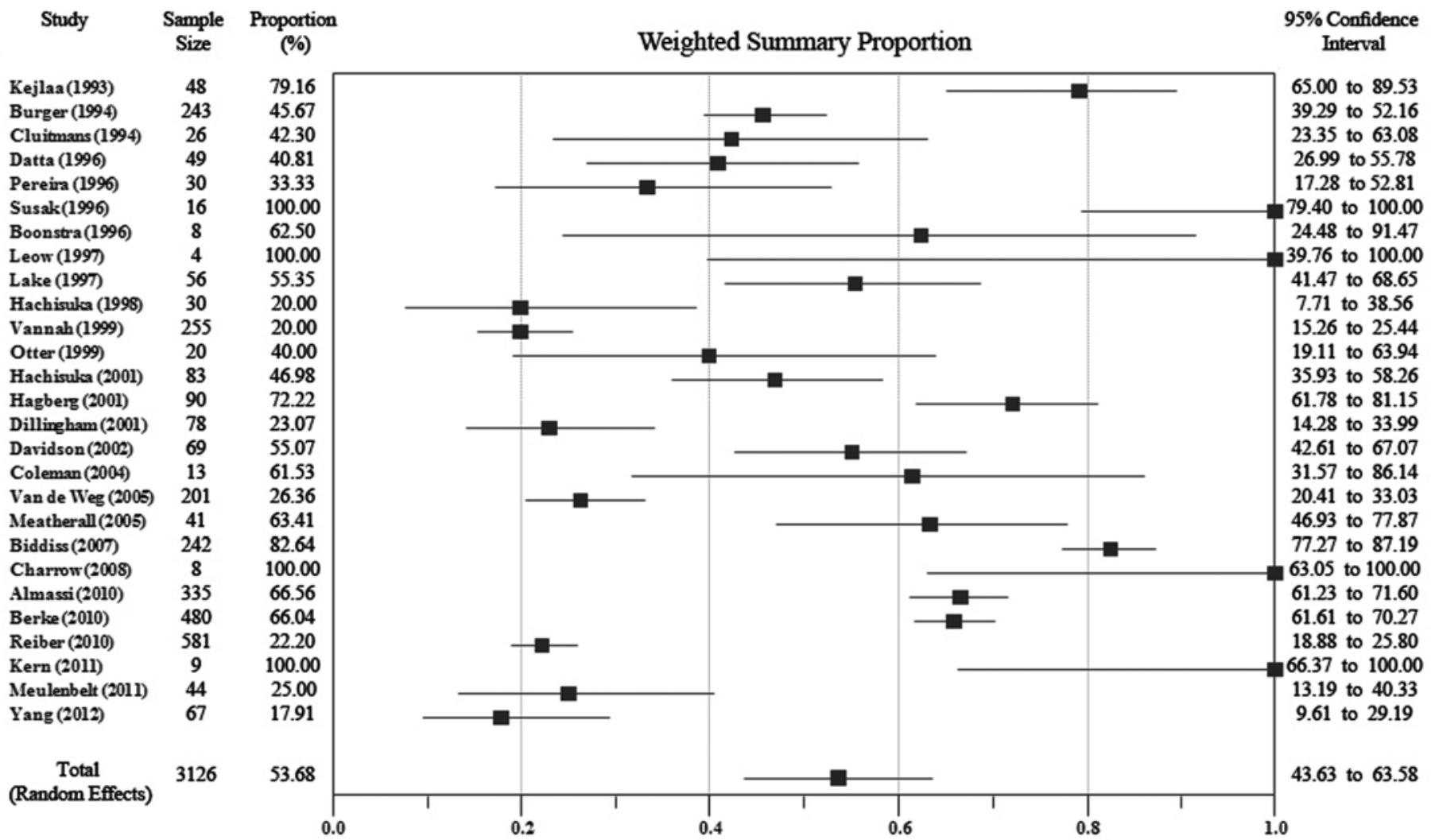

The proportion of amputees with heat/perspiration

Cochran's $\mathrm{Q}=749.97$ discomfort with $95 \%$ confidence interval

$\mathrm{df}=26$

$\mathrm{P}<0.0001$

$I^{2}$ (Inconsistency) $=96.53 \%$

Figure 2.

Forest plot and weighted summary proportions of selected studies that reported number of participants with heat and/or perspiration discomfort. 
quality of life, satisfaction, and prosthesis use, limited attention has been paid to directly resolve this problem by researchers, clinicians, and prosthetic component manufacturers. As a point of view, this could be attributed to the lack of a consensus regarding the prevalence of the problem in the population with amputation. The current study, although a narrative literature review based on the knowledge of the authors, is the first evidence aimed at providing a general insight regarding the high prevalence of thermal problems inside prostheses. This review, based on the available reports of heat and/or perspiration discomfort in the selected studies, identified that at least 53.68 percent of the studied people with amputation complain about thermal-related discomfort inside their prostheses regardless of their prosthesis type and level of amputation.

In the vast majority of people with amputation, all thermal transfer mechanisms, including convection, radiation, evaporation, and conduction, can be disturbed due to the socket barrier, decreased body surface area, and/or vascular disease [8-9,66]. This review identified that the unpleasant thermal environment inside the prosthetic socket is a long-lasting problem complained about by many people with amputation in the literature. Vultee (1958) [15] and Foort (1965) [67], in two preliminary reports of the problem, pointed out that skin maceration of the residual limb can be a result of high perspiration and thermal environment inside the prosthetic socket. Foort correlated this unpleasant environment with the existence of leather-rubber liners, high thickness of prosthesis walls, enclosed distal socket, and snug socket fit [67]. Technological advances in the field of prosthetics followed by the introduction of new prosthesis and residual-limb interface materials could not resolve the problem. The elastomeric liner materials of total surface-bearing sockets adapt to the shape of the residual limb because of their specific viscoelastic property to provide a snug fit for improved weight bearing and suspension. Despite this advantage, these liners prevent ventilation and air circulation at the prosthesis and residual-limb interface [68]. Moreover, low moisture permeability of the liner materials and direct contact of the skin with plastic, silicone, and other inorganic materials prevents sweat evaporation, which causes immersion of the residual limb in a salty liquid pool inside the prosthetic socket that consequently leads to skin irritations $[7-8,15,69]$. The thickness of materials applicable in the construction of prosthetic sockets and liners could influence their thermal conductivity. Klute et al., using a specially designed instrument, measured the thermal conductivity of prosthetic sockets and liners to find the rela- tionship between material temperature transfer ability and residual-limb skin temperature [9]. According to their findings, changing the construction material of prosthetic liners or their thickness would significantly affect the skin temperature of the residual limb [9].

Activity is another factor that could significantly exacerbate the thermal environment inside the prosthetic socket. A small number of studies were found in the literature investigating thermal skin fluctuations of the residual limb during activity. This difficult investigation requires positioning thermistors in the socket-skin interface, which consequently could give the person with amputation discomfort, skin irritation, and ulceration [10]. Peery et al., in a similar investigation, measured the skin temperature of the residual limb in people with transtibial amputation during two positions of rest and walking [29]. They found that wearing the prosthesis at rest and after 10 min of walking would increase skin temperature by $0.8^{\circ} \mathrm{C}$ and $1.7^{\circ} \mathrm{C}$, respectively [29]. The amount of skin temperature increase was $1.5^{\circ} \mathrm{C}$ following walking in the study by Klute et al. [9]. Huff et al. claimed that people with amputation might need more than $1 \mathrm{~h}$ of rest following activity to return to the basal skin temperature [10].

Mapping the temperature distribution of the residual limb is a significant step toward selection of appropriate methods for counteracting the prosthetic socket thermal environment. This investigation could be conducted both experimentally by attaching thermistors to the skin of the residual limb and virtually by simulation software. Peery et al., using three-dimensional finite element analysis, found that in transtibial residual limbs, due to the position of the muscles, the lowest temperature and the coldest region are located at the anterior and distal regions, respectively [70]. To reach this conclusion, they focused on metabolism and blood perfusion of the muscles as two sources of temperature production [70]. Although the thermographic map by Peery et al. seems to be true for most people with transtibial amputation, some factors such as age, lifestyle, and physical condition, by affecting metabolism and perfusion, could contribute to different temperature distribution patterns [70]. In addition, thermal characteristics of tissues depend on their location in the body and may vary among different people.

In spite of previous efforts and current trends to resolve the heat and perspiration discomfort with prostheses, no generally accepted solution has been found. In 2009, Klute et al. gathered and suggested some solutions to the problem in people with lower-limb amputation [4]. These were use of breathable materials for construction 
of prosthetic sockets and liners; perforation of socket walls by cutting some openings; use of antiperspirant medications, powders, and sprays to physiologically decrease skin perspiration; use of psychological methods to reduce thermal discomfort; and design and manufacture of prosthetic-specific cooling systems [4]. Although recently the use of breathable nanomaterials with high thermal conductivity in the structure of prosthetic sockets and liners has been proposed [71-72], there are some doubts about their safety and the manner in which these materials behave over the body surface [73-74]. Perforation of prosthetic socket walls or fabrication of prostheses by perforated materials has weak efficiency, causes sound, and decreases prosthesis durability and suspension $[67,75]$. Furthermore, the socket wall perforations could result in formation of shear stress over the residual limb that consequently could result in soft tissue breakdown. Antiperspirant medications, local ointments, powders, and sprays could decrease perspiration by functional limitation of sweat glands. These materials have an unpleasant odor and are associated with risk of allergic reactions and systemic disturbances $[15,41,76]$. Although Botulinium toxin (Botox) injection could successfully decrease perspiration, it is considered an unacceptable solution. Botox injection is an invasive treatment that could cause pain, hematoma at the injection site, mouth and olfactory tract dryness, and optical problems. Moreover, it requires periodic injections to maintain effectiveness [11]. In some cases, hypnosis, psychotherapy, and biofeedback could be implemented to decrease sweating [77]. These methods have limited generalizability and usually are long-term solutions [77-78]. Many commercially available cooling systems are designed to decrease body temperature in athletes, soldiers, firefighters, and other professionals who need supportive clothes during long activities [79]. These cooling systems could improve comfort and performance [80]. At present, no commercially available cooling system has been introduced to resolve thermal discomfort with prostheses. Fang et al., during analytical and experimental research, designed a fan-based cooling system for a person with transtibial amputation [32]. Their system aimed to remove heat around the prosthetic liner by improving ventilation inside the prosthetic socket [32]. A brief search in patent databases revealed some registered patents for resolving heat and/or perspiration discomfort inside prostheses [81-83]. These patents are mainly related to design and manufacture of fluid (vapor, air, liquid) pressurizing and circulating devices or application of thermoelectric peltier effect cooling systems [81,83]. Some obstacles exist to improving these systems and making them ready to be commercialized.

In the current literature review, due to heterogeneous demographic and methodological characteristics as well as the results of the selected studies, it was difficult to identify the exact prevalence of thermal-related problems. This review, by providing an insight regarding the high prevalence of thermal discomfort with prostheses, could promote future studies on different aspects of the problem. These include identifying how soft tissue responds to the thermal environment of prostheses, how temperature is distributed on the skin surface of the residual limb at different amputation levels, which materials are more suitable for prosthesis construction, which outcome measures should be used for evaluation of thermalrelated discomfort in the population with amputation, and which temperature regulatory systems should be designed for resolving the problem.

\section{CONCLUSIONS}

People with amputation deal with thermal stresses in their daily activities, and in spite of great technological advances in the field of prosthetics, current prostheses are unable to resolve these stresses. Thermal stresses inside the prosthetic socket, in addition to decreased quality of life and prosthesis use, comfort, and satisfaction, could endanger people with amputation with risks of skin problems. Thermal discomfort could disturb socket comfort and general satisfaction with prosthesis use. Due to the importance of thermal discomfort inside prostheses, this review was conducted to provide general insight regarding the prevalence of this problem. Out of 38 reviewed studies, 27 identified the prevalence of heat and/or perspiration discomfort inside prostheses. Based on the pooled participant data from these studies, more than 53 percent of people with amputation complained about thermal discomfort inside prostheses, regardless of their prosthesis type or level of amputation. Considering the high prevalence of heat and/or perspiration discomfort with prostheses, it is suggested that an ideal prosthetic socket, besides the socket and residual-limb stability and weight-bearing comfort, should have the ability to control the residuallimb temperature and moisture. Prosthesis thermal discomfort, as a long-lasting and unresolved problem, needs more attention from researchers, clinicians, and prosthetic component manufacturers on thermal-related biomechan- 
ics of residual-limb soft tissues, proper fabrication technique, and material selection and introduction of efficient thermoregulatory systems.

\section{ACKNOWLEDGMENTS}

\author{
Author Contributions: \\ Study concept and design: K. Ghoseiri, M. R. Safari. \\ Acquisition of data: K. Ghoseiri, M. R. Safari. \\ Analysis and interpretation of data: K. Ghoseiri, M. R. Safari. \\ Drafting of manuscript: K. Ghoseiri, M. R. Safari. \\ Financial Disclosures: The authors have declared that no competing \\ interests exist. \\ Funding/Support: This material was based on work supported by the \\ Iran National Science Foundation.
}

\section{REFERENCES}

1. Kurichi JE, Bates BE, Stineman MG. Amputation. In: Blouin $\mathrm{M}$, Stone $\mathrm{H}$, editors. International encyclopedia of rehabilitation. New York (NY): Center for International Rehabilitation Research Information and Exchange; 2013. p. 1.

2. Ziegler-Graham K, MacKenzie EJ, Ephraim PL, Travison TG, Brookmeyer R. Estimating the prevalence of limb loss in the United States: 2005 to 2050. Arch Phys Med Rehabil. 2008;89(3):422-29. [PMID:18295618] http://dx.doi.org/10.1016/j.apmr.2007.11.005

3. United National Institute for Prosthetics \& Orthotics Development [Internet]. Limbless statistics. Salford (UK): University of Salford; 2009. Available from:

http://www.limbless-statistics.org/-----NASDAB-----.php

4. Klute GK, Kantor C, Darrouzet C, Wild H, Wilkinson S, Iveljic S, Creasey G. Lower-limb amputee needs assessment using multistakeholder focus-group approach. J Rehabil Res Dev. 2009;46(3):293-304. [PMID:19675983] http://dx.doi.org/10.1682/JRRD.2008.02.0031

5. Klute GK, Kallfelz CF, Czerniecki JM. Mechanical properties of prosthetic limbs: Adapting to the patient. J Rehabil Res Dev. 2001;38(3):299-307. [PMID:11440261]

6. Köhler P, Lindh L, Björklind A. Bacteria on stumps of amputees and the effect of antiseptics. Prosthet Orthot Int. 1989;13(3):149-51. [PMID:2514413]

7. Visscher MO, Robinson M, Fugit B, Rosenberg RJ, Hoath SB, Randall Wickett R. Amputee skin condition: occlusion, stratum corneum hydration and free amino acid levels. Arch Dermatol Res. 2011;303(2):117-24.

[PMID:21161543] http://dx.doi.org/10.1007/s00403-010-1111-y

8. Hachisuka K, Matsushima Y, Ohmine S, Shitama H, Shinkoda K. Moisture permeability of the total surface bearing prosthetic socket with a silicone liner: Is it superior to the patella-tendon bearing prosthetic socket? J UOEH. 2001;23(3):225-32. [PMID:11570046]

9. Klute GK, Rowe GI, Mamishev AV, Ledoux WR. The thermal conductivity of prosthetic sockets and liners. Prosthet Orthot Int. 2007;31(3):292-99. [PMID:17979015] http://dx.doi.org/10.1080/03093640601042554

10. Huff E, Ledoux W, Berge J, Klute G. Measuring residual limb skin temperatures at the skin-prosthesis interface. J Prosthet Orthot. 2008;20:170-73. http://dx.doi.org/10.1097/JPO.0b013e3181875b17

11. Kern U, Kohl M, Seifert U, Schlereth T. Botulinum toxin type $\mathrm{B}$ in the treatment of residual limb hyperhidrosis for lower limb amputees: A pilot study. Am J Phys Med Rehabil. 2011;90(4):321-29. [PMID:21765248] http://dx.doi.org/10.1097/PHM.0b013e31820636fd

12. Hagberg K, Brånemark R. Consequences of non-vascular trans-femoral amputation: A survey of quality of life, prosthetic use and problems. Prosthet Orthot Int. 2001;25(3): 186-94. [PMID:11860092] http://dx.doi.org/10.1080/03093640108726601

13. Datta D, Vaidya SK, Howitt J, Gopalan L. Outcome of fitting an ICEROSS prosthesis: Views of trans-tibial amputees. Prosthet Orthot Int. 1996;20(2):111-15. [PMID:8876004]

14. Dudek NL, Marks MB, Marshall SC, Chardon JP. Dermatologic conditions associated with use of a lower-extremity prosthesis. Arch Phys Med Rehabil. 2005;86(4):659-63. [PMID:15827914] http://dx.doi.org/10.1016/j.apmr.2004.09.003

15. Vultee FE. Chemical control of hyperhidrosis of amputation stumps. South Med J. 1958;51(8):966-69. [PMID:13568983]

16. Legro MW, Reiber G, del Aguila M, Ajax MJ, Boone DA, Larsen JA, Smith DG, Sangeorzan B. Issues of importance reported by persons with lower limb amputations and prostheses. J Rehabil Res Dev. 1999;36(3):155-63. [PMID:10659798]

17. Hachisuka K, Nakamura T, Ohmine S, Shitama H, Shinkoda $\mathrm{K}$. Hygiene problems of residual limb and silicone liners in transtibial amputees wearing the total surface bearing socket. Arch Phys Med Rehabil. 2001;82(9):1286-90.

[PMID:11552206] http://dx.doi.org/10.1053/apmr.2001.25154

18. Lake C, Supan TJ. The incidence of dermatological problems in the silicone suspension sleeve user. J Prosthet Orthot. 1997;9(3):97-106. http://dx.doi.org/10.1097/00008526-199700930-00003

19. Levy SW. Skin problems in the amputee. In: Smith DG, Michael JW, Bowker JH, editors. Atlas of amputations and limb deficiencies: Surgical, prosthetic, and rehabilitation principles. 3rd ed. Rosemont (IL): American Academy of Orthopaedic Surgeons; 2004. p. 701-10. 
20. Barnes GH. Skin health and stump hygiene. Artif Limbs. 1956;3(1):4-19. [PMID:13363725]

21. Meulenbelt HE, Geertzen JH, Jonkman MF, Dijkstra PU. Skin problems of the stump in lower limb amputees: 1. A clinical study. Acta Derm Venereol. 2011;91(2):173-77. [PMID:21290085]

22. Baars EC, Dijkstra PU, Geertzen JH. Skin problems of the stump and hand function in lower limb amputees: A historic cohort study. Prosthet Orthot Int. 2008;32(2):179-85. [PMID:18569886] http://dx.doi.org/10.1080/03093640802016456

23. Koc E, Tunca M, Akar A, Erbil AH, Demiralp B, Arca E. Skin problems in amputees: A descriptive study. Int J Dermatol. 2008;47(5):463-66. [PMID:18412862] http://dx.doi.org/10.1111/j.1365-4632.2008.03604.x

24. Meulenbelt HE, Geertzen JH, Jonkman MF, Dijkstra PU. Determinants of skin problems of the stump in lower-limb amputees. Arch Phys Med Rehabil. 2009;90(1):74-81. [PMID:19154832] http://dx.doi.org/10.1016/j.apmr.2008.07.015

25. Pye G, Bowker P. Skin temperature as an indicator of stress in soft tissue. Eng Med. 1976;5(3):58-60.

[PMID:1036225] http://dx.doi.org/10.1243/EMED JOUR 197600502202

26. Newman P, Davis NH. Thermography as a predictor of sacral pressure sores. Age Ageing. 1981;10(1):14-18. [PMID:7211556] http://dx.doi.org/10.1093/ageing/10.1.14

27. Polliack AA, Scheinberg S. A new technology for reducing shear and friction forces on the skin: Implications for blister care in the wilderness setting. Wilderness Environ Med. 2006;17(2):109-19. [PMID:16805147] http://dx.doi.org/10.1580/PR30-05.1

28. Naylor PF. The skin surface and friction. Br J Dermatol. 1955;67(7):239-46. [PMID:13239971] http://dx.doi.org/10.1111/j.1365-2133.1955.tb12729.x

29. Peery JT, Ledoux WR, Klute GK. Residual-limb skin temperature in transtibial sockets. J Rehabil Res Dev. 2005; 42(2):147-54. [PMID:15944879] http://dx.doi.org/10.1682/JRRD.2004.01.0013

30. Fanger PO. Assessment of man's thermal comfort in practice. Br J Ind Med. 1973;30(4):313-24. [PMID:4584998]

31. American Society of Heating, Refrigerating and AirConditioning Engineers; American National Standards Institute. Thermal environmental conditions for human occupancy. Atlanta (GA): American Society of Heating, Refrigerating and Air-Conditioning Engineers; 2004.

32. Fang C, Huang M, Chou Y, Huang G. The study of thermal comfort for below-knee prosthesis. Biomed Eng Appl Basis Comm. 2004;16(1):7-14. http://dx.doi.org/10.4015/S1016237204000037
33. Erikson U, Hulth A. Circulation of amputation stumps. Arteriographic and skin temperature studies. Acta Orthop Scand. 1962;32:159-70. [PMID:13890588] http://dx.doi.org/10.3109/17453676208989570

34. Hafner B. State-of-the-science evidence report guidelines [Internet]. Washington (DC): American Academy of Orthotists \& Prosthetists; 2008. Available from: http://www.oandp.org/grants/MasterAgenda/ AAOP_EvidenceReportGuidlines.pdf

35. Symington DC, Lowe PJ, Mackay S. Semi-flexible sockets for amputation below the knee. Arch Phys Med Rehabil. 1975;56(9):399-404. [PMID:1164180]

36. Rubin G. Some problems of the above-knee amputee. Bull Hosp Joint Dis. 1970;31(1):53-68. [PMID:5449924]

37. Kejlaa GH. Consumer concerns and the functional value of prostheses to upper limb amputees. Prosthet Orthot Int. 1993;17(3):157-63. [PMID:8134275]

38. Burger H, Marincek C. Upper limb prosthetic use in Slovenia. Prosthet Orthot Int. 1994;18(1):25-33. [PMID:8084746]

39. Cluitmans J, Geboers M, Deckers J, Rings F. Experiences with respect to the ICEROSS system for trans-tibial prostheses. Prosthet Orthot Int. 1994;18(2):78-83.

[PMID:7991364]

40. Pereira BP, Kour AK, Leow EL, Pho RW. Benefits and use of digital prostheses. J Hand Surg Am. 1996;21(2):222-28. [PMID:8683050] http://dx.doi.org/10.1016/S0363-5023(96)80104-3

41. Susak Z, Minkov R, Isakov E. The use of Methenamine as an antiperspirant for amputees. Prosthet Orthot Int. 1996; 20(3):172-75. [PMID:8985996]

42. Boonstra AM, van Duin W, Eisma W. International forum: silicone suction socket (3S) versus supracondylar PTB prosthesis with pelite liner: transtibial amputees’ preferences. J Prosthet Orthot. 1996;8(3):96-99. http://dx.doi.org/10.1097/00008526-199600830-00006

43. Leow ME, Kour AK, Inglis TJ, Kumarasinghe G, Pho RW. Fungal colonisation in digital silicone rubber prostheses. Prosthet Orthot Int. 1997;21(3):195-98. [PMID:9453093]

44. Dasgupta AK, McCluskie PJ, Patel VS, Robins L. The performance of the ICEROSS prostheses amongst transtibial amputees with a special reference to the workplace-a preliminary study. Icelandic Roll on Silicone Socket. Occup Med (Lond). 1997;47(4):228-36. [PMID:9231496] http://dx.doi.org/10.1093/occmed/47.4.228

45. Hachisuka K, Dozono K, Ogata H, Ohmine S, Shitama H, Shinkoda K. Total surface bearing below-knee prosthesis: advantages, disadvantages, and clinical implications. Arch Phys Med Rehabil. 1998;79(7):783-89. [PMID:9685091] http://dx.doi.org/10.1016/S0003-9993(98)90356-2

46. Vannah WM, Davids JR, Drvaric DM, Setoguchi Y, Oxley BJ. A survey of function in children with lower limb defi- 
ciencies. Prosthet Orthot Int. 1999;23(3):239-44. [PMID:10890599]

47. Otter N, Postema K, Rijken RA, van Limbeek J. An open socket technique for through-knee amputations in relation to skin problems of the stump: An explorative study. Clin Rehabil. 1999;13(1):34-43. [PMID:10327095] http://dx.doi.org/10.1191/026921599701532108

48. Heim M, Wershavski M, Azizi E, Siev-Ner I, Azaria M. Rehabilitation considerations of prosthetic fittings for Kaposi's sarcoma amputees. Disabil Rehabil. 2000;22(16): 734-36. [PMID:11117593] http://dx.doi.org/10.1080/09638280050192007

49. Hatfield AG, Morrison JD. Polyurethane gel liner usage in the Oxford Prosthetic Service. Prosthet Orthot Int. 2001; 25(1):41-46. [PMID:11411004] http://dx.doi.org/10.1080/03093640108726567

50. Dillingham TR, Pezzin LE, MacKenzie EJ, Burgess AR. Use and satisfaction with prosthetic devices among persons with trauma-related amputations: A long-term outcome study. Am J Phys Med Rehabil. 2001;80(8):563-71. [PMID:11475475] http://dx.doi.org/10.1097/00002060-200108000-00003

51. Davidson J. A survey of the satisfaction of upper limb amputees with their prostheses, their lifestyles, and their abilities. J Hand Ther. 2002;15(1):62-70.

[PMID:11866354]

http://dx.doi.org/10.1053/hanthe.2002.v15.01562

52. Coleman KL, Boone DA, Laing LS, Mathews DE, Smith DG. Quantification of prosthetic outcomes: Elastomeric gel liner with locking pin suspension versus polyethylene foam liner with neoprene sleeve suspension. J Rehabil Res Dev. 2004;41(4):591-602. [PMID:15558387] http://dx.doi.org/10.1682/JRRD.2004.04.0591

53. Van De Weg FB, Van der Windt DA. A questionnaire survey of the effect of different interface types on patient satisfaction and perceived problems among trans-tibial amputees. Prosthet Orthot Int. 2005;29(3):231-39. [PMID:16466153] http://dx.doi.org/10.1080/03093640500199679

54. Meatherall BL, Garrett MR, Kaufert J, Martin BD, Fricke MW, Arneja AS, Duerksen F, Koulack J, Fong HM, Simonsen JN, Nicolle LE, Trepman E, Embil JM. Disability and quality of life in Canadian aboriginal and non-aboriginal diabetic lower-extremity amputees. Arch Phys Med Rehabil. 2005;86(8):1594-1602. [PMID:16084813] http://dx.doi.org/10.1016/j.apmr.2004.11.026

55. Biddiss E, Chau T. Upper-limb prosthetics: Critical factors in device abandonment. Am J Phys Med Rehabil. 2007; 86(12):977-87. [PMID:18090439] http://dx.doi.org/10.1097/PHM.0b013e3181587f6c

56. Charrow A, DiFazio M, Foster L, Pasquina PF, Tsao JW. Intradermal botulinum toxin type A injection effectively reduces residual limb hyperhidrosis in amputees: A case series. Arch Phys Med Rehabil. 2008;89(7):1407-9.

[PMID:18586144]

http://dx.doi.org/10.1016/j.apmr.2007.11.054

57. Almassi F, Emadi N, Mousavi B, Masumi M, Souroush MR. Dermatosis contributing factors in bilateral lower limb war-amputees. Pak J Biol Sci. 2010;13(2):78-82.

[PMID:20415141]

http://dx.doi.org/10.3923/pjbs.2010.78.82

58. Berke GM, Fergason J, Milani JR, Hattingh J, McDowell M, Nguyen V, Reiber GE. Comparison of satisfaction with current prosthetic care in veterans and servicemembers from Vietnam and OIF/OEF conflicts with major traumatic limb loss. J Rehabil Res Dev. 2010;47(4):361-71.

[PMID:20803404]

http://dx.doi.org/10.1682/JRRD.2009.12.0193

59. Reiber GE, McFarland LV, Hubbard S, Maynard C, Blough DK, Gambel JM, Smith DG. Servicemembers and veterans with major traumatic limb loss from Vietnam war and OIF/ OEF conflicts: Survey methods, participants, and summary findings. J Rehabil Res Dev. 2010;47(4):275-97.

[PMID:20803399]

http://dx.doi.org/10.1682/JRRD.2010.01.0009

60. Ali S, Abu Osman NA, Naqshbandi MM, Eshraghi A, Kamyab M, Gholizadeh H. Qualitative study of prosthetic suspension systems on transtibial amputees' satisfaction and perceived problems with their prosthetic devices. Arch Phys Med Rehabil. 2012;93(11):1919-23.

[PMID:22579945]

http://dx.doi.org/10.1016/j.apmr.2012.04.024

61. Østlie K, Lesjø IM, Franklin RJ, Garfelt B, Skjeldal OH, Magnus P. Prosthesis rejection in acquired major upperlimb amputees: A population-based survey. Disabil Rehabil Assist Technol. 2012;7(4):294-303. [PMID:22112174] http://dx.doi.org/10.3109/17483107.2011.635405

62. Yang NB, Garza LA, Foote CE, Kang S, Meyerle JH. High prevalence of stump dermatoses 38 years or more after amputation. Arch Dermatol. 2012;148(11):1283-86.

[PMID:23165833]

http://dx.doi.org/10.1001/archdermatol.2012.3004

63. Ali S, Osman NA, Mortaza N, Eshraghi A, Gholizadeh H, Wan Abas WA. Clinical investigation of the interface pressure in the trans-tibial socket with Dermo and Seal-In X5 liner during walking and their effect on patient satisfaction. Clin Biomech (Bristol, Avon). 2012;27(9):943-48. [PMID:22795863] http://dx.doi.org/10.1016/j.clinbiomech.2012.06.004

64. Gholizadeh H, Abu Osman NA, Eshraghi A, Ali S, Yahyavi ES. Satisfaction and problems experienced with transfemoral suspension systems: A comparison between common suction socket and seal-in liner. Arch Phys Med Rehabil. 2013;94(8):1584-89. [PMID:23262380] http://dx.doi.org/10.1016/j.apmr.2012.12.007 
65. Borenstein M, Hedges LV, Higgins JP, Rothstein HR. Introduction to meta-analysis. Chichester (UK): John Wiley \& Sons; 2009.

66. Charkoudian N. Skin blood flow in adult human thermoregulation: How it works, when it does not, and why. Mayo Clin Proc. 2003;78(5):603-12. [PMID:12744548] http://dx.doi.org/10.4065/78.5.603

67 . Foort J. The patellar-tendon-bearing prosthesis for belowknee amputees, a review of technique and criteria. Artif Limbs. 1965;9(1):4-13. [PMID:5828166]

68. Baars EC, Geertzen JH. Literature review of the possible advantages of silicon liner socket use in trans-tibial prostheses. Prosthet Orthot Int. 2005;29(1):27-37. [PMID:16180375] http://dx.doi.org/10.1080/17461550500069612

69. Highsmith JT, Highsmith MJ. Common skin pathology in LE prosthesis users. JAAPA. 2007;20(11):33-36, 47. [PMID:18035762] http://dx.doi.org/10.1097/01720610-200711000-00018

70. Peery JT, Klute GK, Blevins JJ, Ledoux WR. A threedimensional finite element model of the transibial residual limb and prosthetic socket to predict skin temperatures. IEEE Trans Neural Syst Rehabil Eng. 2006;14(3):336-43. [PMID:17009493] http://dx.doi.org/10.1109/TNSRE.2006.881532

71. Thermally conductive graphite foam [Internet]. Oak Ridge (TN): Materials Science and Technology Division, Oak Ridge National Laboratory; 2010. Available from: http://web.ornl.gov/adm/partnerships/factsheets/11G00941 ID0248 0445 plus.pdf

72. Martin J, Pollock A. Affecting prosthetics at the nano scale [Internet]. Washington (DC): Academy of Orthotists \& Prosthetists; 2008. Available from: http://www.oandp.org/ publications/jop/2008/2008-33.pdf

73. Zhao XC, Liu RT. Recent progress and perspectives on the toxicity of carbon nanotubes at organism, organ, cell, and biomacromolecule levels. Environ Int. 2012;40:244-55. [PMID:22244841] http://dx.doi.org/10.1016/j.envint.2011.12.003

74. Kunzmann A, Andersson B, Thurnherr T, Krug H, Scheynius A, Fadeel B. Toxicology of engineered nanomaterials: Focus on biocompatibility, biodistribution and biodegradation. Biochim Biophys Acta. 2011;1810(3):361-73. [PMID:20435096] http://dx.doi.org/10.1016/j.bbagen.2010.04.007

75. Nakamura T, Hatano E. Process of development and application of porous plastic to prosthetic sockets. J Prosthet Orthot. 1989;1(4):202-10. http://dx.doi.org/10.1097/00008526-198907000-00003
76. González-Pérez R, González-Hermosa R, Aseginolaza B, Luis Díaz-Ramón J, Soloeta R. Allergic contact dermatitis from methenamine in an antiperspirant spray. Contact Dermatitis. 2003;49(5):266. [PMID:14996057] http://dx.doi.org/10.1111/j.0105-1873.2003.0225i.x

77. Hashmonai M, Kopelman D, Assalia A. The treatment of primary palmar hyperhidrosis: A review. Surg Today. 2000; 30(3):211-18. [PMID:10752771] http://dx.doi.org/10.1007/s005950050047

78. Zachariae B, Bjerring P. [Hyperhidrosis. Hypnotherapy of 2 patients with hyperhidrosis.] Ugeskr Laeger. 1990; 152(39):2863-64. Danish. [PMID:2219522]

79. Lopez RM, Cleary MA, Jones LC, Zuri RE. Thermoregulatory influence of a cooling vest on hyperthermic athletes. J Athl Train. 2008;43(1):55-61. [PMID:18335014]

80. Duffield R. Cooling interventions for the protection and recovery of exercise performance from exercise-induced heat stress. Med Sport Sci. 2008;53:89-103.

[PMID:19209001]

http://dx.doi.org/10.1159/000151552

81. King C, inventor. Airflow regulation system for artificial limb and associated methods. United States patent US 20120215324 A1. 2012 Aug 23.

82. Allemand AM, inventor. Device and method for the heating and/or temperature control of prosthesis sockets. United States patent US 20130079893 A1. 2013 Mar 28.

83. Wang B, Zhang C, Zeng C, Kramer LD, Gillis A, inventors. Prosthetic socket apparatus and systems. United States patent US 20130274896 A1. 2013 Oct 17.

Submitted for publication June 6, 2013. Accepted in revised form March 6, 2014.

This article and any supplementary material should be cited as follows:

Ghoseiri K, Safari MR. Prevalence of heat and perspiration discomfort inside prostheses: Literature review. J Rehabil Res Dev. 2014;51(6):855-68. http://dx.doi.org/10.1682/JRRD.2013.06.0133

ResearcherID/ORCID: Kamiar Ghoseiri, PhD Candidate: I-7612-2012; Mohammad Reza Safari, PhD: I-5532-2014

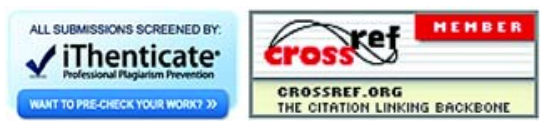


